\title{
Promotion of Female Educators into School Management Positions: A Gendered Perspective
}

\author{
Dominique E. Uwizeyimana \\ Department of Public Management and Governance (PMG), University of Johannesburg \\ Email: uwizeyimanadde@yahoo.com \\ Navela S Mathevula \\ University of Limpopo (TGSL)
}

Doi:10.5901/mjss.2014.v5n20p1203

\begin{abstract}
For centuries the lives of women have been shaped by their reproductive, domestic and nurturing roles, while men have been concerned with business, science, managerial positions, and politics. However, a combination of societal changes and technological developments in the modern and post-modern era has necessitated a broader definition of the social and professional roles of women and facilitated the entry of women into the labour market. However, despite the fact that women have the rights and qualify to occupy any management positions which have been predominantly reserved for their male counterparts, women remain underrepresented in top-management positions. The objective of this article is to find out whether there are gender-based differences in terms of factors identified by scholars as being the causes of under-representation of women in school management positions. The main finding of this research is that while there seems to be no gender based difference on some factors such as family responsibilities, lack of aspiration to management positions, lack of mobility, female educators' fitness to hold management positions and lack of supportive networks as being the main barriers to female educators' promotion in school management positions; the gender based differences exist on other factors such as lack of support from male colleagues, gender stereotyping, female educators' uncertainty about their own abilities to manage. It is hoped that these findings will guide policy makers in crafting better strategies to deal with the problem of under-representation of women in school management positions.
\end{abstract}

Keywords: School management positions, female educators, women in leadership positions, women under-representation, gender stereotypes, glass ceiling.

\section{Introduction}

The development of more reliable and effective birth control experienced in the $20^{\text {th }}$ century has given women the choice of whether or not, and when, to have children, thereby making it possible for them to plan and pursue professional careers (Kiamba, 2008). Thus, besides being mothers and wives, many women now play key roles in study, work and managerial structures of public and private organisations (Kiamba, 2008). Furthermore, economic and societal trends have resulted in the redesigning of work in terms of it being less dependent on the superior physical strength of men (Sczesny \& Stahlberg, 2002). The result of this has been a significant change in the composition of the workforce, influenced also by a significant increase in the participation rate for women in most of the Western countries over the last 50 years of the $20^{\text {th }}$ century (Toossi, 2002). However, even though women have succeeded in making inroads into many of the previously male-dominated areas, jobs remain largely segregated along 'gender lines' (Fernandes \& CabralCardoso, 2003:77; Bettio \& Verashchagina, 2009:6). These gender lines work not only horizontally, dividing traditionally male-dominated occupations from the female ones, but also vertically, in the sense of relatively few women occupying positions at senior management level (Fernandes \& Cabral-Cardoso, 2003:77). Thus, despite the increase of women in the work place, they (women) remain severely under-represented in higher levels of organisations in both developed and developing countries (The Economist, 2009:1). The teaching profession has not been spared this anomaly. For example, a 2012 study conducted in the UK found that "teaching has become a female-dominated profession in both secondary and primary schools" (Gyngell, 2012:1). The same study found that "fewer than one in four recruits are men... and it is set to get worse as the profession sheds older members" (Gyngell, 2012:1). The same sentiments are expressed by Malheiro de Oliveira and Abreu (2012:226), who argue that "Today in France, as in the vast majority of developed or developing 
countries, the rate of female school teachers is around $80 \%$." However, despite the fact that women dominate the primary and secondary teaching profession internationally (in both developed and developing countries), they remain underrepresented in leadership and management positions in both public and private education institutions, at both secondary and primary levels (Cubillo \& Brown, 2003:279). A set of historical, social, economic and organizational factors in both developed and developing countries has been cited by researchers as being the main contributing factors to the working status of women in the $21^{\text {st }}$ century, which in turn has led to their under-representation in management positions (Powell \& Graves, 2003:239). For example, Kellerman and Rhode (2007:6) see the common obstacles to the promotion of women in leadership positions to include the choices they make, such as opting out of full-time professional work to keep home fires burning, as well as the existence of gender bias in leadership opportunities. Others such as Kiamba (2008:13) and Chabaya, Rembe and Wadesango (2009:245) contend that women themselves are often unwilling to compete for top management positions in public and private organisations (including schools). In this context, Kyriakoussis and Sait (2006), in their study on the lack of ambition amongst Greek female teachers to attain managerial positions, found that 94 $\%$ of female teachers did not apply for promotional positions. Another study conducted by Omukaga, Panyako and Wanjiku (2007) on the readiness and willingness of female educators in rural areas of the West Province of Kenya to assume leadership positions in schools revealed that female teachers in primary schools were unwilling to assume leadership responsibilities.

The fact that "the proportion of women decreases at progressively higher levels of managerial hierarchies" in both developed and developing countries, suggests that the discussion regarding social roles and professional gender equality remains far from settled (Ginige, Amaratunga, \& Haigh, 2007). For example, while all these studies have made a significant contribution to the understanding of the barriers to female promotion in management positions, they were almost all based on the perceptions of women and generally ignored the perception of their male counterparts on the same issues. Could there be gender-based differences in terms of factors identified by scholars as being the causes of under-representation of women in school management positions? Before we answer this question, let us first discuss the factors believed to be behind the continued underrepresentation of women in school management position.

\section{Factors Influencing Women's under-Representation in Management Positions}

Over the past two decades, several interrelated gender-based conceptual models have been adapted from the social sciences and used to explain the under-representation of women in educational leadership positions world-wide (Pirouznia \& Sims, 2006:10). In this context, the study of Pirouznia and Sims (2006:10) about the obstacles to women becoming principals in Franklin County, Ohio, and the study of other scholars, such as Growe and Montgomery (2000:2) on the problem of the under-representation of qualified women in leadership positions in the USA, identify three models: the individual perspective model, the systemic gender bias model, and the cultural model. Table 1 summarises the gender-based models and a detailed description of each of these three models is provided below.

Table 1: Gender-Based Models

\begin{tabular}{|l|l|l|}
\hline Models & Emphasis & Cause \\
\hline Individual or Meritocracy & Psychological Orientations & Women are looked to as the cause. \\
\hline Organizational or Systemic Discrimination & Educational System & $\begin{array}{l}\text { The organizational structures and practices of } \\
\text { education which discriminate against women. }\end{array}$ \\
\hline Woman's Place or Socialisation perspective & Cultural and Social Norms & Different socialization patterns for women and men. \\
\hline
\end{tabular}

Source: Growe and Montgomery (2000:3)

\subsection{Individual or Meritocracy perspective}

According to Growe and Montgomery (2000:2), the "meritocracy model, or the individual perspective model", was the first model used by researchers since the eighties to explain the under-representation of women in educational leadership positions. This model has been variously referred to in the literature as the "individual perspective", a set of concepts related to "internal barriers", and "person-centred explanations" (Shakeshaft, 1992 cited in Pirouznia \& Sims, 2006:10). Despite these multiple labels for this model, according to Pirouznia and Sims (2006:10), and Growe \& Montgomery (2000:2), "all seek to explain the persistent and continuing gender segregation in the profession from a psychological orientation". Since this model looks to women as individuals for the cause of their relative failure to attain top 
management positions in terms of personal traits, characteristics, abilities, or qualities (Growe \&Montgomery, 2000:2), individual attitudes, such as self-image and confidence, motivation, and aspirations also fall into this domain (Pirouznia \& Sims, 2006:10). The belief associated with this model is that women are not assertive enough to aspire to leadership positions (ibid, 2006). In addition to this, according to Shakeshaft (1992), this model assumes that the most competent people are promoted solely on their ability. Lack of promotion of women, according to the model, is therefore assumed to be due to the fact that women are not the most competent and able people to be promoted. When the focus is on personcentred causation, according to Van der Westhuizen (1997:545), individuals (in this case, women) are held responsible for their own problems or lack of success. Unfortunately, when individuals are held responsible for their own problems, the solutions to those problems are then framed in terms of changing the defect or improving the individual rather than looking for systemic causes (Pirouznia \& Sims, 2006:10). This arguably distorted belief about women is manifested in statements about women, such as: "they lack self-confidence, they don't want the power, they're just not assertive enough, and they don't aspire to line positions" (Growe, 1999:3, Pirouznia \& Sims, 2006:10). In terms of this perspective, women's relative lack of promotion to administrative positions is due to their own lack of knowledge, skill and willingness to work hard (Welbourne, 2005:1). Equality can thus only come about when women themselves change, when they become better educated, more motivated, and more skilled (Pirouznia \& Sims, 2006:10). Therefore, in order to aspire to management positions, women have first to address their own self-perceptions and the limits they have learned, or internalized, as members of a powerless and oppressed group (Pirouznia \& Sims, 2006:11). The individual perspective, it could be argued, is a very limited one and contrasting with the systemic gender bias model. More recent studies and feminist theorists see this perspective as part of a range of theoretical models besides needing to be related to specific social and socioeconomic contexts. Based on the individual perspective model, most of the authors seem to point to issues such as lack of mobility for women educators, lack of confidence, and lack of aspiration (Neidhart \& Carlin, 2003:4; Pirouznia \& Sims, 2006:22; Chabaya et. al., 2009:240; Oplatka \& Tamir, 2009). Okafor, Fagbemi \& Hassan's (2011) study on the "Barriers to women leadership and managerial aspirations in Lagos, Nigeria: An empirical analysis" also found that "a significant relationship existed between the gender stereotype of a woman manager and her career aspiration, and that women managers possessed all the attributes for top management, but what affected them were the individual factors (gender-imposed) and organizational factors within their context of operation".

\subsection{Organizational or Systemic Discrimination}

Unlike the individual perspective model, the systemic gender bias conceptual model tends to explain the differentials in career aspirations of men and women as an effect of the limited opportunities available to women that accompany systemic gender bias (Pirouznia \& Sims, 2006:11). As the literature shows, in terms of the under-representation of women in management positions, this model turns our attention away from the individual to the educational system itself, and its policies and practices (Khumalo, 2006:3). According to this model, it is the organizational structures, not the individual's own "lack of knowledge, skill and willingness to work hard, desire and aspiration to higher positions" that condition women's behaviours and attitudes in the workplace (Welbourne, 2005:1; Pirouznia \& Sims, 2006:11). According to this model, the problems are therefore external, rather than internal, to women (Neidhart \& Carlin, 2003:4). In other words, if women cannot enter high power positions, it is not due to the way in which they have been socialized as females, but because they are locked into low powered jobs by the male-dominated system itself (Pirouznia \& Sims, 2006:11). This model therefore generally assumes that "men advance to higher levels because they are favoured in promotional practices, and women cannot advance even if they wanted to" because the system which favours their male counterparts does not favour them (Bezzina, 2010:3). In the context of the "systemic gender bias model", according to Pirouznia and Sims (2006:11), women do in fact actively seek management positions, are prepared and readily available to occupy these positions. It is the conditions accompanying recruitment, and selection procedures that are managed largely by men, which prevent women from seeking and obtaining high level administrative positions. The following have been identified as barrier to women's promotion to management positions: based on systemic gender bias model lack of networking, lack of female role models (Marcus, 2013:2), lack of support from colleagues and administrators (Chisholm, 2001:388; Chabaya et al., 2009:06; Chen et al., 2012:240); discriminatory hiring and promotion practices (Baldoni, 2013:1), and lack of mentoring systems in the teaching profession, as well as lack of support systems (from both family and colleagues).

\subsection{Woman's Place or Socialisation perspective}

The third model is identified as the woman's place or social perspective model (Growe \& Montgomery, 1999:3). Pirouznia 
\& Sims (2006:11) refers to this model as "The women's place model", "the social perspective", and Shakeshaft (1992 also cited in Pirouznia \& Sims, 2006:11) refers to it as the "social structure of society" (2006:11). All these terms focus on and emphasize the cultural and social norms that encourage discriminatory practices, and all of them identify 'culture' (i.e. beliefs, values, attitudes dominant in a given society) as the root cause of inequities (Pirouznia \& Sims, 2006:11; Oplatka \& Tamir, 2009). Unlike the previous two models, the cultural model looks for explanations for the under-representation of women in management positions in terms of society as a whole, rather than seeing this as situated in individuals or in education systems per se . The cultural model emphasizes those cultural and social norms that encourage discriminatory practices. According to this model, the ideology of patriarchy can explain why men, and not women, occupy the formal leadership positions in schools and society (Pirouznia \& Sims, 2006:11). The different ways that boys and girls are socialized into our culture, and the socio-cultural stereotypes in terms of "what's ladylike" and "who looks like a leader", as well as social and domestic roles together explain why there exists a lack of female role models in leadership positions (Pirouznia \& Sims, 2006:11). Based on the cultural model, most of the authors seem to point to issues such as gender stereotyping and sex-role stereotyping, as well as family responsibilities (Neidhart \& Carling, 2003; Brownell, 2004; Welbourne, 2005; Pirouznia \& Sims, 2006:15; Chabaya et al., 2009; Chuma \& Ncube, 2010). Since this study is conducted in South Africa, it is important to discuss these factors in the South African context.

\section{The South African Experience}

Although women represent more than half of the world population, there is no country in which women represent half, or even close to half, of the corporate managers (Mazibuko, 2006:106). According to Mathipa \& Tsoka (2006:324), "women are under-represented in higher and middle management positions in higher education, even in the current post-feminist climate when many people claim there is no need to assert that equality must continue to be striven for." South Africa and the teaching profession in particular are not spared this problem. In her study on barriers to the advancement of women in leadership positions in the Gauteng, South Africa, Chiloane-Tsoka (2010:1) found that "despite having a South African Constitution that entrenches equal rights, discriminatory practices, structural inequalities, cultural factors, prejudices and traditional patriarchal society are still alive and well in the South African business environment". While women dominate the teaching profession in South Africa, few of them occupy school management positions. A recent report from the Department of Basic Education in South Africa shows that the total number of female educators in public and independent schools combined is 285252 (68\%), while the number of male educators is only 132852 (32\%) (Department of Basic Education-DBE, 2012). Clearly, while women constitute nearly 70\% of the teaching profession in South Africa, they only constitute 30\%of school managers (Paulsen, 2009:1). According to Mathipa \& Tsoka (2006:324), the problem of having very few women in leadership positions in South Africa came more to the foreground after the advent of the new political dispensation in 1994. Historically, race, culture and ethnicity, religion and language as well as marital status have been identified as the main affecting and defining experiences of women, especially black women teachers in general, and women managers in particular (Moorosi, 2010:1; Lumby \& Azaola, 2011:73). The main focus in the early years of post-apartheid South African tended to blame the apartheid legacy for the under-representation of women in management positions. However, such focus did not explain why women continued to be underrepresented in management positions nearly 20 years later in a democratic South Africa. A number of Acts, such as the Labour Relations Act (No. 66 of 1995), the Employment Equity Act, 55 of 1998, the Employment of Educators Act, Act 76 of 1998, and the principle of Affirmative Action, among many other measures, have been established in order to give effect to the constitutional mandate in South Africa. However, despite these policies, women remain underrepresented in school management positions. Accordingly, as Moorosi argues, more recent studies in South Africa have started to address the subject from an organisational perspective and have explored barriers that women in management still have to overcome in the post-apartheid period (Moorosi, 2010:1). In addition to the factors identified by other researchers in this paragraph, the following barriers have been identified by Mathipa \& Tsoka (2006: 324) as being the major factors that explain the continued under-representation of women in management positions in general and in South Africa in particular:

- $\quad$ "Poor self-image: which is a factor attributed more to women than to men;

- Lack of assertiveness: as a habit more associated with women than men;

- Less career orientation: as a sign of less interest in women as leaders;

- Less confidence: as an argument that women, unlike men, generally lack the will to achieve;

- Poor performance: a myth used as an excuse for employing fewer women in demanding occupations;

- Discrimination: as a sign of low interest in the recruitment of women into leadership positions; and

- Demotion: as a form of punishment thought to suit women better as they are perceived to be lazy and 
arrogant" (Mathipa \& Tsoka, 2006: 324).

Other studies, such as that of Lumby \& Azaola (2011:73), found that "gender remains a potent influence on the career and experience of women, but that it is influenced by other factors such as poverty, race, language and the size of the school". Other studies, such as those conducted by Mazibuko (2006:117), and Zulu, (2009:222) also found that lack of mentorship and lack of formal preparation in the form of professional development programs appear to have been major constraints for women, but only before and after assuming an Head of Department (HoD) position (Mathipa \& Tsoka 2006:222). However, contrary to popular belief that perpetuates a false perception that women lack the personality and the experience needed when faced with tough situations; according to Mathipa \& Tsoka (2006: 324), these disadvantages appear not to have anything to do with the requirements for positions of leadership. A recent study conducted by Moorosi in 2010 found that women in South Africa face these challenges at three levels in their journey to principalship.

In line with the three theoretical models (the individual perspective model, the systemic gender bias model, and the cultural model) as discussed above, Moorosi's three phased model also "revealed that women's experiences are often compromised by the traditional cultural value systems and structural arrangements within the schools that are often less favourable to them" (Moorosi, 2010:16). The first phase, according to Moorosi (2010:2), is the anticipation phase, which prepares women for management. This phase is similar to the "Individual or Meritocracy" discussed here in the sense that "In this phase, the focus is on [women themselves taking the lead in] the development of knowledge and skills that are needed for a management position". While Moorosi's study argues that principals are often appointed on the basis of a successful record as teachers and as such holding a university degree was not sine qua non conditions for being appointed as school principal, the introduction of or the Advanced Certificate in Education (ACE) in School Leadership by the Department of Basic Education suggests that women who aspire to attain principalship positions should attain this certificate in order to avoid being accused of being their own barrier to their development in the future (Moorosi, 2010). According to Moorosi (2010:2), the acquisition of qualifications, training and workshops, as well as participation in informal networks appear to be playing a crucial role at the personal level to prepare women for acquiring management positions.

According to Moorosi (2010), the second phase is the acquisition phase. This phase deals mainly with the problems even suitably qualified and experienced women face when seeking access and entry into organisational management positions. Moorosi's second phase is similar to the "Organizational or Systemic" discussed above in the sense that discrimination is based on an organisation's practices and the culture and norms behind these practices. Moorosi's finding is confirmed by some studies such as that of Lumby and Azaola (2011:75) in the Gauteng and the North West provinces of South Africa which found that "all [respondents] had experienced a response to their gender in negative discriminatory attitudes and, in some cases, aggression or harassment". In terms of education, according to (Moorsi, 2010:2), this is the phase at which women are actively seeking appointment in school principalship positions but are hindered or excluded from attaining these positions because of a lack of proper implementation and enforcement of good policies, such as the Employment Equity Act that exists in South Africa. While Moorosi's finding seems to be contradictory to Zulu (2009:221), whose comparative study of women in management in higher education in South Africa and the United Kingdom found that "that the women who participated in the study experienced little or no challenges and constraints before they advanced to middle management positions; at least not to the same extent as after they were already in the position" without proper implementation of such policies, according to Moorsi (2010:2), and Lumby and Azaola (2011:75), the male normative model of school management, which is derived from the fact that most principalship positions within schools are held by men, will continue to sabotage women since the latter's suitability and acceptability are likely to be assessed according to male attributes.

The third phase, as Moorosi (2010:3) continues to argue, is the performance phase where the actual management function is performed. In this phase, according to Moorosi (2010), the emphasis is placed on the fact that the underrepresentation of women in management positions is a problem even for women who have attained these positions. Because of what other researchers have termed "Woman's Place or Socialisation" or "cultural model", even women who get appointed in school management positions tend to face a range of challenges including lack of support and cooperation from their colleagues, subordinates and families (Chisholm, 2001). Moorosi's study concluded that while women have made tremendous efforts at the "anticipation phase" to prepare themselves for principalship positions, and the "acquisition phase" to make entry into the principalship accessible to women (in terms of policies), there seems to be an insufficient effort to support the women who have broken through the glass ceiling in order to ensure sustainable equity (Moorosi, 2010:17). 


\section{Study Methodology}

The study was conducted in the Lulekani Circuit, which is situated in the Ba-Phalaborwa Municipality of Mopani District, Limpopo Province in South Africa. The population of this study consists entirely of primary school educators in the Lulekani Circuit. There are 21 public primary schools in Lulekani Circuit. The number of all educators at primary public schools in the Lulekani Circuit is 435, with 343 female and 92 male educators. The number of female teachers in management positions in the district is 45 , while the number of male educators in management positions is 33 . In order to ensure the fair representation of all the diverse elements of the study population, a "stratified sampling method", or purposive (rather than random) sampling method was used. The stratification process started with the selection of five out of the 21 public primary schools in the Lulekani Circuit. Out of these five primary schools, three are in rural areas and two are in the urban area of the district. All the schools in the rural areas are no fee paying schools; while the two schools in the urban area are fee-paying schools. These five schools were selected on the basis of their proximity to where the researcher lives in order to minimise the financial and time resources required to conduct the interviews. The second step was to categorise the educators of the five selected schools into two groups on the basis of their gender composition. There are a total of 82 educators in the combined five selected schools, of which 15 are males and 67 are females. As far as gender is concerned, in the five selected schools, one in two males holds a management position, while only one in eight females is in a management position. For the purpose of gender and position balance, the final sample of the study included 20 educators out of 82 . The 20 people in the sample included four males in management positions ( 1 in urban and 3 in rural areas) and four males not in management positions (2 from urban schools), and four females in management positions and eight females not in management positions. One of the four males in management positions and two of the four males not in management positions are from one of the two urban schools. One of the four females in management positions and three of the eight females not in management positions are from urban schools. In the end, $60 \%$ of the respondents were female educators and 40\%were male educators. For a sample to be deemed appropriate, the researcher should select a minimum of $10 \%$ of the given study population (Babooa, 2008:144). Twenty (20) participants out of 82 represented 24. $40 \%$ and the sample chosen is above the $10 \%$ measure. In terms of age balance, most of the respondents in this study (70\%) were between 31 and 45 years old. Twenty (20\%) (4) of the respondents were aged between 46 and 56, while only 10\% were aged between 26 and 30. In terms of teaching experience, 60\% (12 participants) of the respondents had between 9 and 20 years of teaching experience, while $40 \%$ (8 respondents) had between 21 and 26, or more, years of teaching experience. This indicates that most of the respondents would be considered responsible and mature people who would have amassed enough experience to qualify for promotion to management positions. Finally, 60\% (12 out of 20) of participants was female, four of these 12 females were holding management positions, and eight females were not in management positions at the time of the study. The researcher believes that these age and gender variations, as well as the holding or not holding of management positions, fairly reflect the diverse views of the sample and the population of the study.

\section{Results}

The respondents of this study came from different age and gender groups. Figure 1 shows that male respondents tend to agree with female respondents on the following reasons for women remaining under-represented in school management positions: Conflict with family responsibilities (100\% males to $92 \%$ females), women's lacking aspiration to get into school management positions (100\%males and females), female educators lacking mobility (100\% males to $92 \%$ females), women educators not being fit to hold management positions (100\% females and $87.5 \%$ males saying no). Male respondents and female respondents were also less divided on the issue of hiring and promotion practices being barriers to female promotions to school management positions with $50 \%$ of males over $67 \%$ of females indicating this opinion.

However, Figure 1 below also shows a sharp disagreement between male respondents and female respondents on issues such as gender stereotyping, female educators' uncertainty about their own abilities to manage, and lack of (family and colleague) support as being the reasons why women remain under-represented in school management positions. While all (100\%) female respondents considered gender stereotyping and lack of (family and colleagues) support to be some of the main reasons why they are unable to get into school management positions, all (100\%) of the male respondents disagreed. Finally, while $100 \%$ of the male respondents tended to think that female educators' own uncertainty about their abilities to manage is the reason why they remain under-represented in school management positions, only $33 \%$ of the females agreed. The majority of the female respondents (67\%) said that they were aware and confident of their capabilities in terms of taking school management positions and of succeeding in these positions if given the opportunity. Following this is a summary of the differing perceptions between male and female respondents, 
irrespective of whether the respondents were in school management positions or not.

Figure 1: Female versus male educators' perceptions

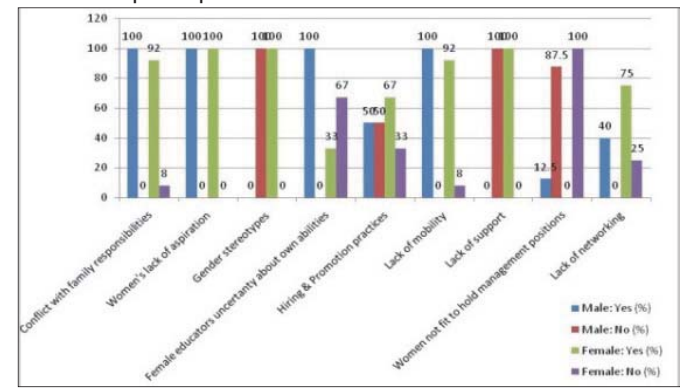

Figure 1 created by the researchers.

\section{Analysis and Interpretation}

The analysis of the results in this research shows marked differences as well as similarities between the perceptions held by the group of female respondents and those held by the male respondents on some, but not all the factors named as barriers to women's promotion to school management positions.

\subsection{Female versus male educators' perceptions: Agreement}

Figure 1 shows a high level of agreement among male and female respondents that women are not 'weak', and that they are in fact fit to hold management positions if given the opportunity. All the female respondents rejected the assumption that female educators are weak and not fit to take up school management positions, and 88\%of males rejected this assumption (i e. 88\% of male respondents think women are not weak and are in fact fit to be school managers). As one female respondent puts it:

\section{I think it is wrong to say women have weakness when it comes to management and leadership positions. Nowadays} women are empowered to take positions and doing very well compared to male.

The findings in this section suggest the existence of a gradual change in women's self-perception (see for example Mathipa and Tsoka 2006) and in men's perception of women's ability to become good and successful managers. One of the male respondents supported the female respondents' view by citing many examples of strong women leaders and managers in South Africa:

Recently, women have shown the world that they can also be good leaders and managers. We have so many examples of good women leaders and mangers in South Africa. Women are capable.

However, while it is very important to note that both men and women are starting to change their perception of women's ability to manage schools, further analysis shows that this change of perception is not enough to achieve equal representation of women in school management positions. For example, as Figure 1 continue to show, both males $(100 \%)$ and females (92\%) tended to agree that family responsibilities remains one of the main factors that hinder female educators from taking up school management positions. Commenting on the possibility of the demands of a management position distracting her from her family responsibilities and her caring role, one of the female respondents said:

I don't aspire to occupy any management position at school because that would make it difficult for me to fulfil my family responsibilities at home. I would like to be promoted but as a woman, I am worried that management position here at school will make it difficult for me to fulfil my family roles effectively.

The sentiment of this female respondent who is not in a school management position tends to confirm what male respondents also see as another challenge facing women who take up management positions. One of the male respondents who participated in this research complemented this sentiment by saying that: 


\begin{abstract}
Female educators, who are in management positions are at a disadvantage sometimes; because, even those women who are courageous enough to take up management positions in their schools are often forced to relinquish their positions in order to follow their husbands when their husbands are promoted to management positions in other provinces.
\end{abstract}

The findings in this study corroborate the findings of other studies such as Brownell's (2004) study which found that family responsibilities constitute a major barrier to women's advancement to higher positions because accepting these higher positions often requires these women to leave home, relatives and the family in order to move across the country for better opportunities resulting in the loss of quality time with their families (Brownell, 2004). Based on these findings, it can be argued that the challenge for women seems to be finding the balance between keeping one's family happy and handling the responsibilities that come with holding a school management position. Such lack of the balance between keeping one's family happy and handling the responsibilities also explains why female teachers seem to have given up the aspiration to school management position. As shown in Figure 1, there seems to be an agreement between all the males (100\%) and all female educators (100\%) that female educators do indeed lack aspiration to management positions in schools. In fact, a number of female educators who participated in this research reported that they enjoyed being teachers and wanted to stay in their classes with their learners rather than aspiring to school management positions.

However, the researchers would argue that this apparently widely held perception that women lack aspiration needs to be seen in the context of other limiting factors such as family responsibilities, and lack of family and co-workers' support. Therefore, it can be argued that while a lack of aspiration is a critical barrier to women's promotion into school management positions, dealing with lack of aspiration is not likely to yield the desired results if society does not change the way it views women's role in society and their abilities to perform in school management position. The other barrier to women's promotion closely related to lack of sufficient support and encouragement from families and work colleagues is lack of mobility. As shown in Figure 1 there is an agreement between male and female respondents that a lack of mobility is a barrier to female educators' promotions into school management positions, with $100 \%$ of males and $92 \%$ of female respondents confirming this. This finding is in line with other studies conducted in different contexts, such as the one conducted by Akpinar-Sposito in 2012, in other countries such as France and Turkey Zimbabwe and Kenya which also found that "many women managers would refuse to relocate if asked to because of their children's education and social support systems (Akpinar-Sposito, 2012:7; Chabaya et al. 2009:05). Once again, in order to help women overcome the challenge of lack of mobility, one has to help them first deal with challenges facing women as a result of society and cultural obligations or expectations as argued by Moorosi (2010) in the previous sections of this article. Having family and co-workers support is vital in the fight against underrepresentation of women in school management positions also because, Figure 1 shows that male and female educators are less divided on the issue of whether hiring and promotional practices constitute barriers to female educators' promotion to school management positions, with $50 \%$ of males and $67 \%$ of female respondents seeing these practices as barriers while the rest thinking they are not. In fact, there was a perception among half of the male respondents that the current hiring and promotion practices do indeed favour women over men. One of the female respondents who had a very positive view of the legislation intended to bring about employment equity and considered it to have had a clearly observable effect on the promotion of women to various management positions in the education sector and joyfully said:

Our government is one of the best in the world in fighting discrimination in all sectors of life, including the promotion of female educators. Since the promulgation of several policies, such as the Equity Act and the Employment of Educators Act, we have seen many women appointed in management position, such as Head of departments, principals, Circuit Managers, District Senior Managers and Members of Executive Councils (MEC's). I am very proud that our current Minister of education in South Africa, Angie Motshekga, is a woman.

This positive view on government policies was also echoed by those male respondents:

\begin{abstract}
We salute our [South African] government for eliminating gender discrimination in the Department of Education and the whole country. The target that has been set by the government of South Africa is 50:50 representation of both male and female in all work places, which is progressing very well. We see in other interviews when four females and one male are shortlisted because of gender equity policy. While there is still a long way to achieve these targets, we believe that the gap will be closed very soon.
\end{abstract}

\title{
6.2 Female versus male educators' perceptions: disagreement
}

However, despite the agreement on certain factors which are believed to be behind the continued underrepresentation of 
women in school management position reported in the above paragraphs; Figure 1 also shows that there is a sharp disagreement on some other important issues. These include gender stereotyping, with males (100\%) holding the view that gender stereotyping is not (or no longer) a barrier to women's promotion to school management positions, while all of the females $(100 \%)$ thought that gender stereotyping is indeed still a serious barrier to their taking up those positions. Thus, while women tend to view their challenges from a "women's place or socialisation perspective", male respondents tended to look at women's challenges from an "individual or meritocracy" perspective. For example, in trying to demonstrate how gender stereotype affects females who are in school management position, one of the female respondents said:

The school management role is generally regarded as a male role. People still think of women as unfit for management positions. Even though this view is held by most people, I personally believe that it is wrong. For example, recently I asked for help from the Circuit Office and guess what help I got from them. They sent a male trainee to come to help me. When he came we could see that he does not have the big picture. But everybody said he is great with administrative work. I personally think it is the perception some people have that we need male principal.

This female view seems to confirm some male respondents' views that: "Gender stereotypes cannot be used as an escape goat for women's lack of competency". Thus the challenge seems to be for women to improve their educational and management competencies in order to increase their chance of being accepted as competent managers in the management positions currently dominated by men. This is very important in order to deal with the issue of lack of confidence which also seems to be dividing the respondents. As Figure 1 show, there seems to be disagreements along gender lines regarding the proposition that female educators' uncertainty about their own abilities to manage is a barrier to their being promoted to school management positions. For example, all (100\%) male respondents tended to believe that female educators' uncertainty about their abilities to succeed in school management positions is the reason why they do not get promoted, or push to be promoted, into these positions. One male respondent confirmed his male colleagues' perceptions of woman's lack of confidence and assertiveness:

\begin{abstract}
I believe, female educators are not confident and are not aware of their own abilities. This respondent went on to clarify his opinion by stating that: "This is evident when we are in group discussions, and they will choose men to lead the group".
\end{abstract}

However, the male respondents' views were generally rejected by female respondents' with $67 \%$ of them saying that they are aware and confident of their own abilities as managers. It is however a serious concern to find that at least $33 \%$ of female respondents agreed with the views of the male respondents that women themselves are uncertain about their own abilities to manage schools. The fact that $33 \%$ of female believe women are not aware of their abilities explains why women tended to rate their own abilities to take up management positions lower than their male colleagues did in earlier studies such as the one conducted by Heiskanen in 1993.

Thus, while all the female respondents $(100 \%)$ tended to think that lack of such support constitutes a barrier to female educators' promotion; all the male respondents thought that this is not (or at least should not be) the case if women were able to go out and use their God-given talent to manage. One of the male respondent commented:

I do not think female managers lack support from their colleagues. They are given support unless their competency level is of an unacceptable standard. To gain support they need to be competent.

\title{
7. Conclusion
}

The specific aim of the collection of the evidence was to find out whether there are specific gender-based differences in terms of factors identified by scholars as being the causes of under-representation of women in school management positions. After having carefully considered all evidence collected using the two data collection methods (i.e. literature review and structured interviews), it became clear that male and female respondents tend to agree on some the barriers to women educators' promotions but disagree on the others. The fact that the analysis of the findings above has highlighted gender based disagreement on factors such as a lack of support from male colleagues, gender stereotyping, and uncertainty about females' own abilities to manage is a matter of serious concern and suggests the need for an open and frank discussion about what the male educators have to do to build trust between themselves and their female colleagues. Thus while women need to work on their own self-image, confidence and skills, they will definitely need family support in order to increase mobility, aspiration and ultimate accession to school management positions. 


\section{References}

Akpinar-Sposito C (2012) Career barriers for women executives and the Glass Ceiling Syndrome: the case study comparison between French and Turkish women executives. http://hal. archives-ouvertes. fr/docs/00/73/85/19/PDF/Paper_for_conference_Ist. for_HAL. pdf (accessed: 02 August 2013).

Babooa SK (2008) Public participation in the making and implementation of policy in Mauritius with reference to Port Louis' Local Government. Unpublished Doctoral thesis. Pretoria: University of South Africa.

Baldoni J (2013) Few Executives Are Self-Aware, But Women Have the Edge. http://blogs. hbr. org/cs/2013/05/few_executives_are_selfaware.html (accessed: 19 August 2013).

Bettio F \& Verashchagina A (2009) Gender segregation in the labour market Root causes, implications and policy responses in the EU. European Commission's Expert Group on Gender and Employment (EGGE).

Bezzina M (2010) It's a long way to the top: getting past the barriers for aspiring principals. Australian Catholic University.

Brownell J (2004) Women in hospitality management: General managers' perceptions of factors related to career development. International Journal of Hospitality Management, 13(2):101-117.

Chabaya O, Rembe S \& Wadesango N (2009) The persistence of gender inequality in Zimbabwe: Factors that impede the advancement of women into leadership positions in primary schools. South African Journal of Education, Vol. 29. issue: 2. Pp. 1-13.

Chen A, Doherty N. \& Vinnicombe S (2012) "Developing women's career competencies through an EMBA," Gender and Leadership in South African Educational Administration. Gender and Education, Vol. 13:387-399.

Chiloane-Tsoka GE (2010) Perceptions of Barriers to the Advancement of Women in Management and Leadership Positions in South Africa, Gender and Behaviour, Vol 8, No 2 (2010).

Chisholm L (2001) Gender and leadership in South African Educational Administration. Gender and education, 13: 387-399.

Chuma M \& Ncube F (2010) Operating in men's shoes: challenges faced by female managers in the banking sector. Journal of sustainable development in Africa, (12) (7):172-185.

Cubillo L \& Brown M (2003) Women into Educational Leadership and Management: International Differences. Journal of Educational Administration, (41) (3)278-279.

DBE (2012) Annual surveys for ordinary schools: Report on the 2009/2010. http://www. education. gov. za/LinkClick. aspx?fileticket=\%2B5BphKZWqLA\%3D\&tabid=358\&mid=1261 (accessed: 05 July 2013).

Fernandes E \& Cabral-Cardoso C (2003) Gender asymmetries and the manager stereotype among management students, Women In Management Review, 18(1/2): $77-87$

Ginige K, Amaratunga D \& Haigh R (2007) Gender Stereotypes: A Barrier for Career

Development of Women in Construction. http://usir. salford. ac. uk/9826/1/147_K_Ginige_Gender_Stereotypes_A_Barrier_for_ Career_Development_of_Women_in_Construction. pdf (accessed: 27 June 2013).

Growe R \& Montgomery P (2000) Women and the leadership paradigm: Bridging the

gender gap. National Forum Journal, 17E, 1-7. http://www. nationalforum. com/Electronic\%20Journal\%20Volumes/Growe, \%20Roslin\%20Women\%20and\%20the\%20Leadership\%20Paradigm\%20Bridging\%20the\%20Gender\%20Gap. pdf (accessed: 28 June 2013).

Gyngell K (2012) Our schools need tough guys teaching teenage boys, not feminised men changing infants' nappies. http://www. dailymail. co. uk/debate/article-2175009/Our-schools-need-tough-guys-teaching-teenage-boys-feminised-men-caring-primarylevel-infants. html (accessed: 29 July 2013).

Kellerman B \& Rhode DL (2007) Women in leadership: the state of play and strategies for change. Jossey-Bass: San Francisco.

Khumalo SS (2006) Challenges faced by women as school managers in primary schools in Warmbaths area. Submitted in partial fulfilment of the requirements for the degree Magister Technologia: Education, in the Department of Postgraduate Studies in Education Tshwane University of Technology.

Kiamba J (2008) Women and leadership positions: social and cultural barriers to success. Wagadu, 6:7-26.

Kyriakoussis A \& Saiti A (2000) Under-representation of women in public primary school administration: the experience of Greece. $A$ referred academic Journal for Leadership in Learning, 10(5).

Lumby, J \& Azaola,C (2011) Women principals in small schools in South Africa, Australian Journal of Education, 55(1): 73-85.

Lumby J \& Azaola C (2013) Women principals in South Africa: gender, mothering and leadership. British Educational Research Journal. DOI: $10.1002 /$ berj.3028.

Malheiro de Oliveira JDB \& Abreu AA (2012) The need for male teachers: Some thoughts from Brazil; Anuário Brasileiro de Educação Básica de 2012.

Marcus LP (2013) Developing Women Leaders: Five Essentials. http://www. linkedin.com/today/post/article/20130101170009-60894986developing-women-leaders-five-essentials (accessed: 8 July 2013).

Mathipa ER \& Tsoka, EM (2006) "Possible barriers to the advancement of women to leadership positions in the education profession" South African Journal of Education, 21(4).

Mazibuko F (2006) Women in academic leadership in South Africa: Conventional executive or agents of empowerement? Alternations, $13(1): 106-123$.

Moorosi P (2010) South African female principals' career paths: understanding the gender gap in secondary school management. Educational Management Administration \& Leadership 38(5): 547-562.

Neidhart H \& Carling P (2003) Pathways, incentives and barriers for women aspiring principalship in Australia Catholic Schools. Paper 
presented NZARE/AARE Conference Auckland.

Okafor EE, Fagbemi AO \& Hassan AR (2011) Barriers to women leadership and managerial aspirations in Lagos, Nigeria: An empirical analysis, African Journal of Business Management, 5(16): 6717-6726.

Omukaga D, Panyako N \& Wanjiku J (2007) Are female colleagues ready for appointments on affirmative actions? Unpublished paper presented at the regional meeting of the Kenya Association of Education Administration and management; 44 (6):604-624.

Oplatka I \& Tamir V (2009) 'I Don't Want to Be a School Head' Women Deputy Heads' Insightful Constructions of Career Advancement and Retention. Educational Management Administration Leadership, 37: 216-238.

Paulsen SE (2009) Challenges faced by female managers in schools within the Nelson Mandela Metropolis. Submitted In Partial Fulfilment of the Requirements for the degree of Magister Educationis in the faculty of education, Nelson Mandela Metropolitan University.

Pirouznia M \& Sims M (2006) The Obstacles in Women's Pathway to Principalship, http://ro.ecu.edu. au/cgi/viewcontent.cgi?article= $1090 \&$ context=theses\&sei-redir=1\&referer $=$ (accessed on 28 June 2013).

Pirouzinia M (2013) Voices of Ohio Women Aspiring to Principalship. Journal of International Women's Studies, 14(1).

Powell GN \& Graves LM (2003) Women and men in management. (3rd edition). Thousands Oaks: Sage.

Sczesny S \& Stahlberg D (2002) The influence of gender-stereotyped perfumes on leadership attribution. European Journal of Social Psychology, 32: 815-828.

Shakeshaft C (1992) Gender and supervision in school personnel. Education Digest, 57 (6).

The Economist (2009). Women in the workforce: Female power, http://www.economist.com/node/15174418 (accessed: 29 July 2013 ).

Toossi M (2002) Century of Change: The U. S. Labor Force, 1950-2050, Monthly Lab.

Rev. 15 (2002). http://heinonline.org/HOL/LandingPage?collection=journals\& handle=hein. journals/month125\&div=48\&id=\&page= (accessed: 29 July 2013).

Van der Westhuizen PC (1997) Effective Educational Management. Cape Town: ABC Press (Pty) Ltd.

Welbourne T (2005) Women "Take Care,"Men "Take Charge:" Stereotyping of U. S.

Business Leaders Exposed. http://www. rochester.edu/sba/100years/PDFs/Women\%20Take\%20Care\%20Men\%20Take\%20Charge.pdf (accessed: 4 July 2013).

Zulu CB (2009) A comparative study of women in management in higher education in South Africa and the United Kingdom, PhD Thesis, submitted at UNISA. 